\title{
The Socio-Economic Impact of Dam Construction
}

\author{
Ade Sadikin Akhyadi ${ }^{\mathrm{a}}$, Oong Komar ${ }^{\mathrm{a}}$, Dadang Yunus Lutfiansyah ${ }^{\mathrm{b}}$ \\ ${ }^{\text {a} U n i v e r s i t a s ~ P e n d i d i k a n ~ I n d o n e s i a, ~ B a n d u n g, ~ I n d o n e s i a ~}$
}

Corresponding e-mail: ades.akhyadi@upi.edu,oongkomar@upi.edu,dadangyunus@upi.edu

\begin{abstract}
The national development encouraged by the government through the establishment of community infrastructure determines the rate of growth of the economy of society, including the construction of reservoirs, although spawned a wide range of new social problems. Construction of reservoirs interpreted as an effort to improve the facilities and infrastructure of Indonesian society in a sustainable manner by utilizing the advancement of science and technology as well as attention to the challenges of global development. This research methodology use case study, with qualitative approach. The data were collected through direct observation of active participants and in depth interview, document study like literatures, official documents, pictures, and so on. The data analysis were data collection, data transcription, coding, data grouping, triangulation and conclusion. This study examines the socialeconomic impact of the construction of Jatigede water reservoir conducted in the communities affected by the dam construction. The purpose of this research in general is to obtain an overview of the socio-economic impact of Jatigede water reservoir construction.
\end{abstract}

Keywords - Socio-Economic Impact, Dam Construction, Local Community

\section{INTRODUCTION}

The history of thinking about development tinged with the evolution of its significance; in the progress, the development is seen as a multidimensional process, which includes not only economic aspects but also the major changes in the social, behavioral, and institutional structures. The national development encouraged by the government through the establishment of community infrastructure determines the rate of growth of the economy.

One of the national development projects pertaining to the physical livelihood of its people is the construction of water reservoir in Kampung Jatigede Kulon, Cijeungjing Sumedang, Indonesia. Twenty eight villages covering five districts are inundated in the construction. About 40.000 people lose their houses, along with 3.100 hectares farmland and 1.200 hectares forest that are also gone. The main problem is there are still a lot of the inhabitants who have not yet received compensation for their inundated houses and land from the government. Besides, the people's kerohiman is much overlooked. Everything to be done definitely brings about the negative and positive effects. Some of the inhabitants get benefit from the dam construction, particularly if their inundated houses and land get well-compensated. As for what discussed earlier, there are still many residents were missed and did not receive compensation from the government.

Social order in the community affected by the dam construction changes almost in all aspects, including the change in the culture of farming into town fishing, the loss of local culture, and the sinking of dozens of historic sites, especially those related to the history of Sumedang. The other effect is the potential conflict in the relocation area, violations of human rights, and resettlement issues. Considering the previous dam construction cases, the history of the transfer process of whole population mostly turned out unfavorable.

According to Soekanto [1] in relation to cultural change or the changes happened in the cultural elements is called a change of culture. It can be said that a change of culture is the condition where there is a discrepancy between the cultural elements that differ from each other which resulted in a state of mismatched function for life. The change of culture leads on to emerge of social mobility/mobilization in the society.

Social mobilization will keep going hand in hand with the modernization of life. The changes of patterns of social behavior could result from the current development, construction, technology advances, and natural circumstances. The number of foreign culture influences as well as the people's consumptive behavior drive to the acceleration of social change. The social change in general can be defined as a process of shifting or a change of structure in social life, including a more innovative mindset, attitudes, and social behavior in order to live a more dignified life.

The conceptualization of social impacts of infrastructure development is inherently complex, with a 
multitude of social impacts occurring over various time, space and value dimensions. Shields (1974,p. 265) in Katrina (2016; 1) [2] defined social impacts as "responses of social systems to the physical restructuring of their environments", a definition which does not help define these impacts in a way that can be operationalized, though.

Under the situation and background, the researcher puts some interest in and purposely seeks for in-depth understanding of the socio-economic impact of jatigede water reservoir construction (a study on affected community of the construction of jatigede reservoir Sumedang).

\section{RESEARCH METHOD}

This research methodologi use case study, with qualitatif approach. Case study was conducted in this research to gather in-depth understanding and draw a deep description on the research problem in order to reveal the uniqueness and distinctiveness of this study. The report of the research will be consisting of a description of the research background, condition, and the characteristics of respondents. Five heads of family, one village official, one public figure, and two of nongovernmental organizations were taken as the subject of research.

Qualitative approach is employed in this study, and is expected to generate a detailed cognition of the object under study as a whole. The appropriateness of using a qualitative approach is also based on the problems to be highlighted in this research with the considerations that, 1) is easier when faced with reality, 2) provides a direct nature of the relationship between researcher and respondents, 3 ) is more sensitive and more adjustable to the joint effects that encounter the patterns of values (Moleong, 1998: 5). [3]

The data were collected through direct observation of active participants and indepth interview, document study like literatures, official documents, pictures, and so on. The data analysis were data collection, data transcription, coding, data grouping, trianggulation and conclusion.

\section{RESULTS OF THE STUDY}

\section{A. Socio-Psychological Condition of the Community Affected by Jatigede Dam Construction}

Psychologically the people affected by Jatigede dam construction felt restless, confused, and depressed when about to be relocated. The unfair compensation, having no idea where to move or how to deal with new surroundings in the relocated area, and the loss of job or livelihood were the major causes of psychological condition of the people that is more sensitive and easily provoked. In addition, social condition in the new environment that differs from their former situation impedes them to socialize, to mingle or communicate with the new surroundings. Lack of knowledge in business, business motivation, as well as reading business opportunities causes the limitation in the investment for the purposes of their own lives. Particularly the lack of life skills and vocational skills of the people is one of the causes that drive their unstable psychological state.

The potential inventory discussed in this research is the condition of natural resources, namely a reservoir that can be used for fishery (floating fish farms), food (processed or raw) materials production, and the potential of fish market. Another potential is the institutional and social cohesion in the community. One of the institutional potential to support the people affected by the dam construction is the presence of community advocacy center and learning center (NGOs) for them as the initiation and driving force of empowerment in the community. Social cohesion in this concern refers to the potential coming from a high empathy of the people in the community in their efforts to advance and empower each other, likely in providing funding for developmental programs and knowledge sharing by experts with other communities, especially regarding the empowerment of the community affected by Jatigede dam construction [4] .

Therefore by identifying the problems as well as the potentials of the dam construction, it can be figured out the needs required by the affected people to be made a priority to be achieved as a primary goal in the empowerment of the affected community. In this study the main priority to be achieved in the community empowerment consists of three following goals for its people: 1) to able to work, 2) to be capable of entrepreneurship and 3) to have independent life.

Based on the interview conducted by the researcher with the local authorities that is BAPPEDA Sumedang, represented by Kasubid Sosial of the handling of Jatigede reservoir, he said that the government has been providing the relocation for the people in Blok Tanggulan Desa Conggeang Kulon Kecamatan Conggeang Sumedang. However they were reluctant to move and remained in their flooded place. Another proof of concerns by the government is that the people were still allowed to work on their farms or fields in the area of inundation even when they should have no longer worked on the land and the compensation for the land has been paid.

The people still made use of the wetland that have been paid on the grounds that the land (in the inundation area) was very fertile where the soil texture could increase the fertility, coupled with the watering and the cold weather that made them comfortable to keep staying there. The government turned to be understanding by not asking for their harvest and encourage the people to work on and produce more agricultural products so they have a decent income and could make a lifesaving for their future.

Being questioned about the empowerment of the affected community, the local authorities said that they had already had it done. However in the implementation of the programs, the needs of the said community should be considered. The people affected by the dam construction are mostly farmers, and when they are migrated into urban areas they have no skills other than farming. BAPPEDA Sumedang has been initiating some life skill training in corporation with the Local Government Unit and the central government to provide such training for the affected community adjusted to their relocation destination. The government has also asked some enterprises in Sumedang to help provide empowerment programs that support the 
authorities to find the solution regarding the social impact of the dam construction.

\section{B. Educational Condition of the People Affected by Jatigede Dam Construction}

Based on the data obtained, there are twenty three schools including twenty one public elementary schools and two junior high schools that were inundated for the sake of Jatigede reservoir construction. The attempts to meet the basic rights of education for the children affected by the dam construction were conducted through sending the chilldren to school in their new living environment, although the process was quite difficult because they already felt comfortable at their former home. Per-block (per-family) relocation policy were sufficient to help in resolving these obstacles, where the children could still went to school with their relatives so they feel safe for being with someone they close to and could be able to befriend with new people in a new circumstance. However, there occurred some complaints about the long distance between their home and school and also worries since in the new relocated area, the children need to go through a highway to be able to reach their school.

\section{Kinship and Social Relations of the People Affected by Jatigede Dam Construction}

Family provides a huge influence to the continuity of human life. Family is the main pillar of communication and dissemination as well as the comfort of life of a person. For the people affected by Jatigede dam construction, they were living comfortably before their home and land need to be inundated. The close distance between the houses enables them to have a chat or make a visit with the relatives that stay nearby. Thus the close kinship and attachment among them make the community mostly relocated themselves along with all their family. By doing so, the people could be able to live comfortably surround by their relatives.

The community affected by Jatigede dam construction spread across several areas in Ujungjaya, Situraja, Pawenang, Pakualam, Cisurat, and Wado. The data obtained in Environment Anyar Dusun Cimuncang show that the migrants (of the community affected by the dam construction) were able to adjust with a new circumstance and quite comfortable to live with the natives in the new environment. The process of unification between the newcomers (the migrants) and the natives to be merged into local association was conducted in integrated manner. Kircther (2016) [5] says Social activities encountered both by the newcomers and the natives run harmoniously as seen in the participation of the newcomers in the road paving program; along with the natives they work together to reach the common purpose.

\section{DISCUSSION}

The findings of this study resulted in the following discoveries, 1) that the people affected by Jatigede dam construction were psychologically disturbed. The people experienced restlessness, confusion, and depression when relocated. Having no place to stay and no job/jobless caused them to be more sensitive psychologically and easily provoked, which then become the contributing factors resulting in difficulties in socializing, interacting, and adapting with a new environment. In other reseach, Rahmati and Nazarian (2010) [6] analyzed the economic, social and environmental impacts of the settlements affected by the construction of the Gotvand Olia and Karoon dams. The findings of that study strengthen that the villages and agricultural lands behind the dams were subject to many negative social and economic effects and that the consequences were two times greater for rural communities.

2) The educational situation during Jatigede dam construction was not conducive for the people affected by the construction. The educational services were hampered due to lack of facilities and infrastructure as well as the difficulty of accessibility faced by students that caused the declining of their knowledge, cultural, and historical values. 3) the kinship and social relations before the construction of Jategede dam were very close, harmonious, full of sympathy and empathy, in contrary to the situation after the inundation, relocation, provision of compensation, and kerohiman in which the relationships turned distant and broken, although the process of unification between the migrants (the people relocated) and the native community proceeded in harmony.

\section{CONCLUSIONS}

Psychologically the people affected by Jatigede dam construction felt restless, confused, and depressed when about to be relocated. The unfair compensation, having no idea where to move or how to deal with new surroundings in the relocated area, and the loss of job or livelihood were the major causes of psychological condition of the people that is more sensitive and easily provoked.

Moreover, the attempts to meet the basic rights of education for the children affected by the dam construction were conducted through sending the children to school in their new living environment, although the process was quite difficult because they already felt comfortable at their former home.

The last, the close kinship and attachment among people there make the community mostly relocated themselves along with all their family. By doing so, the people could be able to live comfortably surround by their relatives.

\section{REFERENCES}

[1] Soekanto S. (2007). Sosiologi Suatu Pengantar. Jakarta: PT Raja Grafindo Persada.

[2] Shields, M.A., (1974). Social impact studies: an expository analysis. Environ. Behav. Retrieved from http://eric.ed.gov/?id=EJ128316

[3] Moleong (1998). Metode Penelitian ; Jakarta : Rajawali Press

[4] Wikipedia. (2015, Oktober 28). Tentang Kami : Waduk. Diakses Oktober 29, 2015, dari Wikipedia: http:www.wikipedia.org/wiki/waduk

[5] Kirchherr, J., Charles, K.J. (2016) , The social impacts of dams: A newframework for scholarly analysis, Environ Impact Asses Rev

[6] Rahmati, A.R., Nazarian, A., (2010). Economic-social and environmental impacts of settlements subject to displacement due to 
[8] Y. Yorozu, M. Hirano, K. Oka, and Y. Tagawa, "Electron spectroscopy dam construction (case study Gotvand upper Karun river). Environ. Stud. 1 (2), 66e53,

[7] M. Shabanzadeh-Khoshrody et al. / Journal of Cleaner Production 135 (2016) 549e557 Analytical investigation of the effects of dam Construction on the productivity and efficiency of farmers, Journal of Cleaner Production 135 (2016) 549e557 sciencedirect.com studies on magneto-optical media and plastic substrate interface," IEEE Transl. J. Magn. Japan, vol. 2, pp. 740-741, August 1987 [Digests 9th Annual Conf. Magnetics Japan, p. 301, 1982].

[9] M. Young, The Technical Writer's Handbook. Mill Valley, CA: University Science, 1989. 